Many of the most tragic and telling points in the narrative are tucked away in footnotes: take, for example, the reference to the killing of Jews "at an average daily rate of 5,000 persons" for the years 1943 and 1944 (p. 321), and the plight of physicians and dentists still among the 'hard core' of unrepatriated refugees-men whom no country would accept, although they "had served their fellows for years in the assembly centres, and some had thereby missed opportunities for resettlement" (pp. 430-31). Where it is impossible to maintain this muted tone Mr. Proudfoot quotes from other authors-when dealing with the conditions found in German extermination camps, or when describing the illegal migrations of Jews bound for Palestine, for example.

The book's brief conclusions deal mainly with administrative problems that arise in schemes for the relief, repatriation and resettlement of refugees. But it will interest many others besides those concerned with such schemes. To what groups and institutions do Europeans give their loyalties, and what happens when loyalty to the State conflicts with other loyalties? What are the factors that contribute to the success of an international authority? What are the crucial differences between military and civil organizations, and on what terms can the two collaborate ? On these and other questions this book throws useful light-light which is sometimes all the more revealing for being indirect and unintended.

\section{V. DonNISON}

\section{THEORY AND PRACTICE OF RHEOLOGY}

Rheology

Theory and Applications. Edited by F. R. Eirich. Vol. 1. Pp. xiv + 761. (New York: Academic Press, Inc. ; London : Academic Books, Ltd., 1956.) 20 dollars.

TT would seem that this work, of which two further volumes are shortly to appear, is an attempt to unify the theory and much of the practice of rheology. Already quite a large collection of books on rheology is available, including a series of seven International Rheology Monographs ; though the latter, with but one exception, do not deal primarily with fundamental theory. The British Society of Rheology has listed, in a recent Bulletin, more than fifty books on this still youthful branch of physics, though it must be admitted, again, that many of these are either students' text-books or deal only with very specialized fields.

While it cannot be denied that unification is needed, the tables of contents of these three volumes leave one wondering whether this new work will indeed contribute much to this unification and also whether the later volumes especially may not prove to contain much the same material as that which is already available elsewhere, often written by the same authors. However, the first volume, here under review, is the least subject to this criticism.

Until recent times, when the widespread appearance of 'Weissenberg effects' among industrial materials has directed attention to the need for a tensorial approach, most practical rheologists were content with unidirectional tests, ignoring any components of stress and even of strain and flow, in other planes. Even for ad hoc purposes, this attitude is becoming increasingly difficult, and perhaps it is not too much to ask the industrial rheologist of to-day to learn enough tensor theory to follow Prof. Reiner's admirable treatment of "Phenomenological Macrorheology". Whether he can also be expected to master Riemannian geometry is more questionable; perhaps younger readers will feel that an elderly reviewer is over-pessimistic in his doubts on these matters.

It is not possible here to mention all the sixteen essays in this volume. Suffice it to say that leading authorities discuss plasticity and hardening of metals, theory of dislocations, high-pressure rheology, theories of viscosity and of large deformations, problems of visco-elastic behaviour, optical and acoustical methods of testing, as well as many of the rheological properties of high polymers.

The book is admirably produced and printed-as it should be for the price-and I can find only one major misprint : the mis-spelling of Dr. Treloar's name throughout a whole chapter.

While sympathizing with the editor in his task of unifying the work of so many authorities from many lands, one cannot help regretting that he has decided not to attempt any standardization of symbols. It is to be hoped that, in the later volumes, at least the most widely used concepts will have a unified symbolism. If this is quite impossible, at least it should be insisted that the authors' tables of nomenclature at the end of each essay should be complete.

Were this a work of less importance, I would hesitate to make these rather stringent criticisms. But the book is a most important contribution by writers of outstanding authority, nor are the later volumes yet apparently completed. It is therefore hoped that there may be time to give consideration to some of these points before the work is finished. If this can be done, and especially if too much duplication can be avoided, the work will doubtless prove to be a major contribution to rheological literature.

G. W. Scotr Brarr

\section{GRASS FARMING}

\section{Grassland Farming in the Humid Northeast}

By Prof. Ford S. Prince. (The Grassland Farm Series.) Pp. xii +441 . (Princeton, N.J.: D. Van Nostrand Company, Inc. ; London: Macmillan and Co., Ltd., 1956.) 45s. net.

Theory and Dynamics of Grassland Agriculture By Prof. Jack R. Harlan. (The Grassland Farm Series.) Pp. $x+281$. (Princeton, N.J.: D. Van Nostrand Company, Inc.; London: Macmillan and Co., Ltd., 1956.) 42s. net.

THESE two volumes are complementary to each other in the Grassland Farm Series edited by W. A. Wheeler. Both works lay the utmost stress upon the grassland sward as a crop having the dual purpose of providing livestock food and improving the suil. Prof. Ford Prince's book sets out to be intensely practical and to offer detailed guidance to the farmers of the north-eastern region of the United States. Practical day-to-day information is offered on such matters as seeds mixtures, liming and manuring for good grass production, pasture management, grass cunservation and grass for use by different classes of 